\title{
INDUSTRIAL PROPERTY PROTECTION IN THE CONTEXT OF ENTERPRISES' INTANGIBLE ASSETS SECURITY
}

doi: $10.2478 /$ czoto-2020-0042

Date of submission of the article to the Editor: 4/01/2020

Date of acceptance of the article by the Editor: 20/01/2020

Renata Stasiak-Betlejewska ${ }^{1}$ - orcid id: 0000-0001-8713-237X

Czestochowa University of Technology, Poland

Abstract: The right use of creativity and innovation in business leads to increased competitiveness and development in your company. The progressive use of modern technologies and their presence in the economy causes problems in managing these assets and defining intangible property and their protection, which is directly related to the basic processes of making important decisions in the development of the enterprise. Everyday industrial designs (most often: e.g. new packaging designs), trademarks (e.g. product names, advertising slogans, logos) and other technical solutions (utility models, recipes or inventions), which are the result of creative work in company. The lack of protection of the above intellectual (industrial) goods as a consequence often leads to the appropriation of the idea by the competition and their commercialization on the market without the participation of enterprises.

Keywords: innovations, industrial property, enterprises

\section{INTRODUCTION}

Intellectual property is the subject of many legal acts, moreover, the sources of these rights can be divided into national and increasingly important international acts. The basic laws regulating intellectual property law in Poland are:

- Act of 30 June 2000, the Industrial Property Law (Journal of Laws 2017 item 776);

- Act on Copyright and Related Rights (Journal of Laws 2018 item 1191).

The protection of the intellectual property is to enable the inventor or creator to obtain legitimate benefits from his invention or work. It should also enable the widest possible dissemination of works, ideas and new know-how (Rushing 2019; Drahos, 2016).

At the same time, it may not restrict freedom of expression, the free flow of information or the protection of personal data, including data protection on the Internet. In the absence of effective measures to implement intellectual property rights, innovation and creativity are hampered, and investment is falling. It is necessary to ensure the effective application in the Community of substantive law in the field of intellectual property, 
which now forms a significant part of the acquis. In this respect, the means of implementing intellectual property rights are of paramount importance for the success of the internal market (George, 2017; Kasprzycki et al. 2008).

Industrial property rights, i.e. trademarks, patents, utility models and industrial designs, are intangible assets of an enterprise. Often, these assets are also the company's greatest asset value. Protected industrial property rights may be the subject of trading, including in-kind contributions, sales and licenses. As assets, these rights can be used in the enterprise for balance sheet purposes (e.g. to increase the book value of the enterprise) as well as for tax (in tax planning). Importantly, the use of industrial property rights as an enterprise's assets requires a valuation of their value. It is a process in which, based on economic, accounting, legal and marketing data, the value of a given right, e.g. a trademark, is estimated. One of the basic methods of valuing IP rights is the income method, based on the so-called hypothetical license fees (Priebe, 2019; McKeough, 1996; Merges, 1995).

Trade secrecy is one way to keep inventions and discoveries out of the hands of competitors to protect an investment in R\&D. As long as no one else knows the Coca-Cola formula, the Coca-Cola Company does not have to worry about competition from outsiders who did not share the cost of developing it. But secrecy only works for inventions that can be exploited commercially without disclosure, such as manufacturing processes. Many inventions and discoveries are self-disclosing once they are put on the market in the form of a product, and thereafter may only be protected through a patent. Even when secrecy is feasible, it might not be desirable. From the perspective of an innovating firm, disclosure of underlying technology might help in the marketing of a new product, and from a broader social perspective, secrecy might impede further technological progress in the field (Eisenberg et al. 1996).

European patent applications, which are of higher quality than national patent applications, have an even higher impact on sales increases with a lag of 3 years after the priority year. These results lend support to the use of patent data as an output indicator of R\&D activities for business applications as well as empirical research (Holger 2001). The number of Polish patent applications to the European Patent Office (EPO) increased in 2018 by almost $20 \%$. The rate of increase in the number of applications was one of the largest in Europe - according to the just published report summarizing the activities of EPO last year. The number of patent applications submitted to the European Patent Office by Polish inventors, enterprises and research centres increased by 19.7 percent in 2017. The Polish rate of increase in the number of applications was one of the largest in Europe and definitely exceeded the average for 38 EPO member states, which amounted to $+3.8 \%$ (European Patent Office, 2018).

In total, last year, Polish applicants filed 534 patent applications with EPO (in 2017 it was 446 applications). Universities were the driving force behind Polish patent activity - to a greater extent than in most other European countries. The first place in the ranking of Polish applicants was taken by the Jagiellonian University with 12 patent applications, followed by respectively: Zakłady Farmaceutyczne Polpharma S.A. (6 applications), AGH (5 applications) and ex aequo Gdańsk University of Technology and Fakro Group (4 applications each).

Almost a quarter (24.2\%) of applications came from Warsaw and the surrounding area. Next in terms of the number of patent applications were: Małopolskie (16.9\% of all applications), Pomorskie (9.8\%), Śląskie (8.8\%) and Dolnośląskie (8.3\%). The vast ma- 
jority of applications from Poland (71\%) concerned various types of technologies, especially transport, civil engineering and thermal processes (each of these sectors accounted for $7 \%$ of all Polish patent applications). Nearly $6 \%$ of all applications concerned pharmaceutical products, and 5\% each: medical technologies, biotechnology and computer technologies (Ministerstwo Rozwoju Departament Strategii Rozwoju, 2017).

Overall, last year, EPO received over 174 thousand. European patent applications - an increase of $4.6 \%$ compared to 2017 . The number of applications from China increased by $8.8 \%$ (which is the lowest result in five years). The United States ranks among the top submissions from $25 \%$ of the total number of entries, followed by Germany, Japan, France and China. EPO has seen an increase in the number of patent applications from most European countries - except France and Finland (European Patent Office, 2018).

\section{RESEARCH FIELD CHARACTERISTIC}

At present, no one needs to be convinced of the importance of knowledge and intellectual property generated in the course of conducting business activity for economic entities. These goods are often the success of entrepreneurs on the market. Despite extensive regulation of intellectual goods, not every such product is, however, protected in the same way. In addition, the legislator requires specific conditions to be met in order to create protection. In this way, intellectual property of entrepreneurs can be protected as works, after meeting the requirements set out in the Copyright Act, they can also, if they have the appropriate features, be protected as a patent for an invention or an industrial or utility design. The question, however, what to do with such intellectual products that do not fall into any of these categories, or, if they already fall, then entrepreneurs are not interested in making them public (which in the case of industrial property is a necessary condition for granting protection). In these situations, regulations regarding the protection of business secrets and classified commercial information come to the rescue (Abott et al. 2019).

According to the EPO report (2018), there is no consensus among the Member States of the Union as to the definition of a trade secret. Some countries have included this definition in industrial property laws (Italy and Portugal), others construct what is trade secrets based on case law and the TRIPS Agreement (Denmark, Belgium, Luxembourg, Germany, Austria, Spain, France, Cyprus, Greece, Ireland and Great Britain). In Poland, what a business secret is can be found in the Act on Combating Unfair Competition, where Art. 11 paragraph 4 stipulates that the secret of an enterprise is understood as undisclosed technical, technological, organizational information of an enterprise or other information of economic value on which the entrepreneur has taken the necessary measures to maintain its confidentiality (Berisha, 2019). Similarly, this issue was regulated by Romania - there also the definition was included in the Act on counteracting unfair competition. In turn, the Czech Republic, Lithuania and Hungary define what trade secrets are in their civil codes. It is also worth mentioning the specific solution of Finland - there the definition is included in the penal code. The only European country that has a special regulation devoted to trade secrets is Sweden - there is a special law on the protection of trade secrets.

However, the EU legislature has ensured that Directive 2016/943 contains a definition of business secrets. According to art. 2 points 1 of the directive, information that meets the following conditions is a trade secret (Pila and Torremans, 2019): 
- they are confidential in the sense that, as a whole or in a particular set and collection of their elements, they are not generally known or easily accessible to people from the circles who usually deal with this type of information;

- they have commercial value because they are kept secret;

- they have been subjected by a person who, in accordance with the law, controls them, activities which are reasonable under the circumstances to keep them secret.

This definition is essentially identical to that contained in the TRIPS Agreement (Art. 39 paragraph. 2).

The manner and level of protection of classified commercial information also varies between the various EU countries. There are several approaches here. Two countries have decided to extend the trade secrets to the protection of intellectual property rights, and therefore the claims provided for in Directive 2004/48 / EC on the enforcement of intellectual property rights will apply. A similar solution was adopted in Finland, despite the lack of explicit regulation. A large proportion of Member States rely on protection against unfair competition (including Poland). Countries such as Belgium, France, Luxembourg and the Netherlands protect trade secrets by using claims arising from torts, while common law countries rely on the breach of confidence tort. A special solution regarding the scope of protection has been adopted by France - apart from the aforementioned tort protection, production secrets have been included in the French Intellectual Property Code to a limited extent, however, claims relate only to disclosure of such secrets by employees and managers (Menell et al. 2019).

The EPO report indicates a number of differences in the protection of trade secrets by individual Member States. This negatively affects cross-border protection. It is considered by experts to be weak. The problems include, among others, the burden of proof showing whether unlawfully used information is a business secret, provisions scattered in many different legal acts, which are additionally accused of being unclear or even insufficient, lack of requirements for secrecy during court proceedings, the problem of measuring compensation and the lack of specialized courts dealing with trade secret matters in some Member States (Kur et al. 2019).

\section{RESEARCH FINDINGS}

There are two primary ways of analysing patent information: qualitative and quantitative. The qualitative method shows more closely the content of the individual patent documents. The quantitative method results in statistical processing. These two methods have quite different objectives and different ranges of applications. Patent analysis can be displayed by visual representation using bar graphs, polygonal line graphs, pie charts, radar charts and other charts/graphs, which are called 'Patent Maps'. Visualization is an especially effective way of representing the results of this type of analysis (Hong 2003).

The research proposal was thoroughly reviewed and numerous key words were selected for patent searches (Basberg 1987; Smyth 2013). Today, electronic databases, analytical software products and private service providers with their own proprietary value-added patent or technology databases are available for assisting in the analysis of patent information. In 2018, the Patent Office received 4,207 applications for registration of inventions and granting patents filed by domestic (Polish) entities. It is almost 300 more than in 2017, but slightly less than in 2016 and over 400 less than in the 
record-breaking 2015, when 4,679 applications were submitted. In general, looking at the space of 5 years, it can be said that the number of applications for registration of inventions and granting patents oscillates at a similar level of about 4 thousand annually.

The situation is different when it comes to filing inventions with the Patent Office by foreign entities. From 2012, when their number reached 247, there are fewer and fewer applications. In 2018, foreign entities submitted only 115 inventions to the Patent Office. As in previous years, most of the applications for inventions in the Patent Office among foreign entities are made in our country by Germans and Americans.

It is impossible not to notice that with the reduced interest in registering inventions in the Polish Patent Office by foreign entities, the number of European patents in force on the territory of Poland is increasing. As at December 31, 2018, the number of these patents was 64,366 . Of course, the decrease in the number of patent applications filed by the Patent Office by foreign entities is not inversely proportional to the increase in the number of European patents in force in Poland. The number of the latter increases much faster than the decrease of the former. Four years ago, in 2014, the number of European patents in force in Poland was 34,179 , which is almost half as much as today. A kind of "displacement" of the Polish patent (ie granted by the Patent Office) by the European patent can also be seen by the total number of patents that are in force in Poland. As at December 31, 2018, there were 64,366 European patents in force on our territory, while Polish patents only 21,806. In 2018, Polish entities submitted 534 applications for registration of inventions in the European Patent Office, which placed Poland in 25th place among all countries in the world in terms of the number of applications for inventions in this office. This is not a particularly bad result, but considering our European neighbours, such as Germany (26,734 notifications in 2018), France (10,317 notifications in 2018) or even a small Denmark (2,390 notifications in 2018), we are not doing the best.

As for the utility model application by Polish entities, their number remained for years at around 950 per year. In 2018, there were exactly 943 applications. In the case of foreign entities, the number of utility model applications in the Patent Office shows a downward trend and in 2018 it reached only 115. For comparison, five years earlier, in 2013, the number of utility model applications by foreign entities was 175 .

In 2018, Polish entities submitted 1,081 applications for registration of industrial designs at the Patent Office. It is more than in 2017, in which 971 applications were submitted, but looking from a long, long-term perspective, the trend is definitely decreasing. For comparison, in 2010 Polish entities submitted 1,723 applications for registration of industrial designs to the Patent Office.

It should not be surprising then that the number of applications submitted by Polish entities to EUIPO for registration of industrial designs is practically constantly increasing. In 2018, there were 4,073, i.e. almost 4 times more than applications for registration of industrial designs submitted to the Patent Office. Such a number of applications for registration of industrial designs in EUIPO gave our country the 7th place among all countries in the world in terms of the number of applications submitted. With the exception of 2016, when Poland took 5th place in this ranking, we have been in 7th place for years. We are ahead of Germany, USA, Italy, France, China and Great Britain. In 2018, however, Polish entities submitted more applications for the registration of industrial designs than entities from Spain, Switzerland, Denmark, Sweden or the Netherlands. 
Total number of industrial designs registered in the Patent Office is systematically falling and as at 31 December 2018 was 8,476 . For comparison, in 2014 this number was 10,626 industrial designs. Contrary to inventions and industrial designs, it is difficult to talk about a similar downward trend in the number of trademarks applied for and registered at the Patent Office.

In 2018, 12,811 applications for registration of trademarks were received from Polish entities to the Patent Office.

In comparison with previous years it can be said that this figure remains at a similar level of around 13 thousand. applications per year. In the case of foreign entities, in 2018 the Patent Office received 856 applications for registration of trademarks. In addition to the continuing high level of applications for registration of trademarks at the Patent Office, the upward trend is also shown by the number of trademarks submitted by Polish entities for registration at EUIPO. In 2018, these notifications were submitted in 3,879 , which gave Poland the 10th place among all countries from which the entities submitting came.

As with inventions, utility models and industrial designs, it is worth observing the trend in trademark registration at the Patent Office in 2019. This is due to changes in trademark law that came into force earlier this year, one of which assumptions is theoretically expanding the catalogue of signs that can be registered as trademarks, by removing the requirement of their graphic representation.

A recently published initial report on the protection of business secrets in European Union countries published by the EU Intellectual Property Office. This is related to Directive 2016/943 of the European Parliament and of the Council on the protection of classified know-how and classified commercial information (business secrets) against their unlawful acquisition, use and disclosure, adopted on 8 June 2016, whose transposition deadline expired on 9 June 2019 year. The publication of the initial report is an opportunity to look at issues regarding the protection of business secrets across Europe. Figure 1 presents the number of European patent applications filed with the EPO for the ten technology fields with the largest number of applications in 2019.

1. Digital
communication

Fig. 1. European patent applications include direct European applications and international (PCT) applications that entered the European phase during the reporting period Source: Source: EPO. Status: 27.1.2020. 
Data presented in digital communication saw by far the strongest growth in patent applications, overtaking medical technology for the first time in a decade. This reflected the pace of development surrounding $5 \mathrm{G}$ technologies. The second fastest-growing field was computer technology, fuelled by the rise of artificial intelligence.

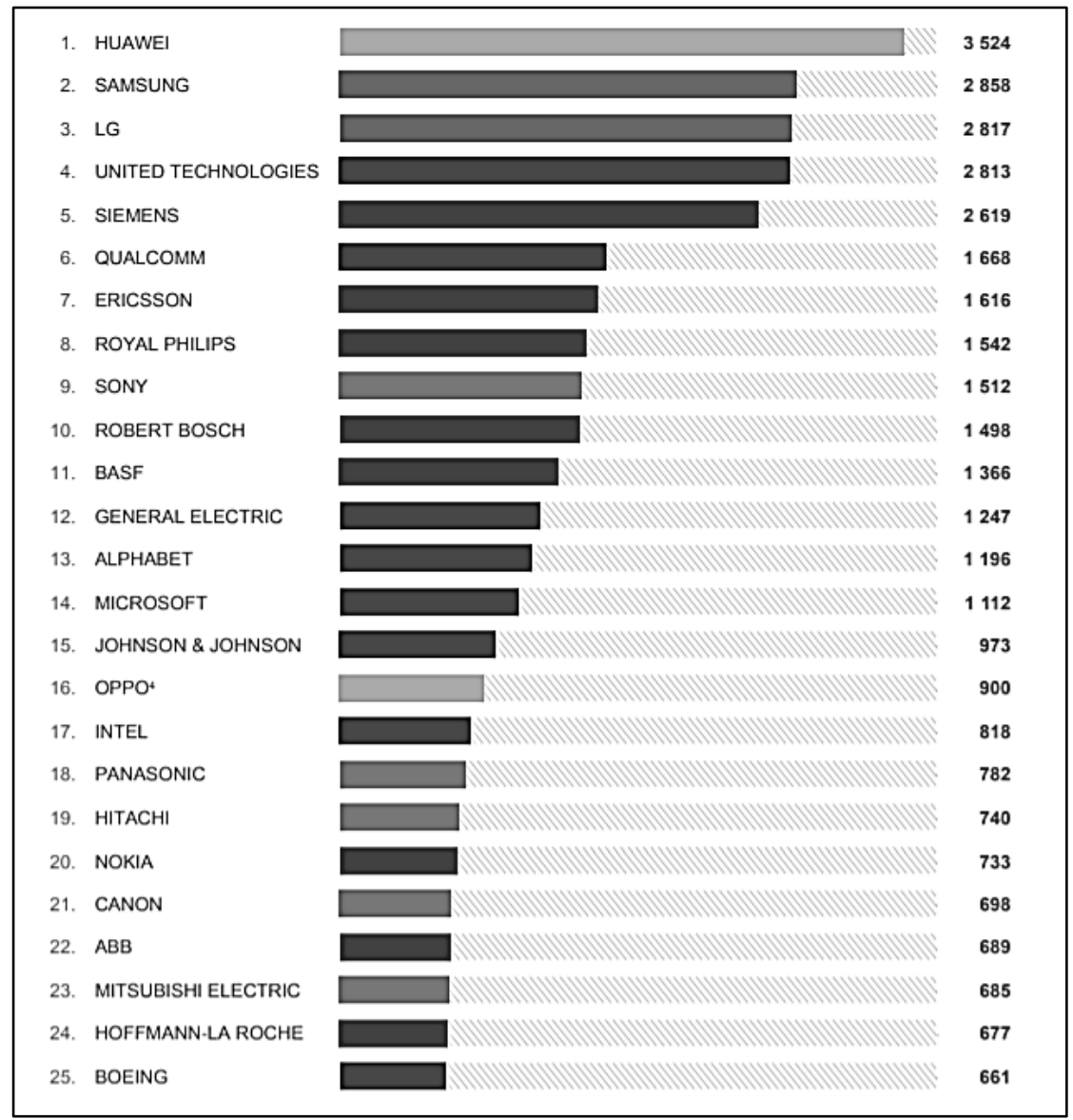

Fig. 2. The largest applicants on patents at the EPO, indicating their country of origin Source: Source: EPO. Status: 27.1.2020.

Figure 2 presents the ranking of the main consolidated applicants at the EPO in 2019 (first-named applicant principle). It is based on European patent applications filed with the EPO, which include direct European applications and international (PCT) applications that entered the European phase during the reporting period (2020). Data confirms the highest share of patent applications concerning companies related to digital communication inventions.

\section{CONCLUSION}

The strategy in the scope of managing the process of intellectual property production in an enterprise requires securing the rights to intellectual products created as part of its operations.

The choice of the right protective route is dictated by the nature of the protected intangible asset, as well as the strategy the entrepreneur should choose. At the beginning of business activity, commercial goals and development plans should go hand in hand with protection actions. An important element that is crucial from the point of view of choosing a strategy for the protection of intangible assets, especially for enterprises in 
the SME sector - are often insufficient financial resources limiting the use of formal protection methods.

At a time when intangible property was created by many people, then rights to it arise for the benefit of these people together - on the basis of joint ownership. The most important element of joint ownership is the intellectual contribution of each of these people to the created good. Engagement that does not have creative elements (e.g. involving the performance of supporting activities or strictly following the instructions of the team leader) does not entitle to obtain the status of an artist in accordance with the provisions. The scope of each creative contribution determines the amount of participation in common law. In the absence of contrary provisions, it is presumed that the contributions of individual contributors are equal, therefore it is recommended to properly regulate the amount of shares by agreement between the contributors contained in the contract.

\section{REFERENCES}

Abott F.M., Cottier T., Gurry, F., 2019: International Intellectual Property in an Integrated World Economy, Wolters Kluwer Law \& Business.

BL Basberg, 1987. Patents and the Measurement of Technological Change: A Survey of the Literature, Research Policy 131.

Berisha B., 2019: Platforms Regulation in the Digital Single Market Strategy Illegal Content and Intellectual Property as a Key Challenge, European Research Studies Journal, XXII, 1, 186-191.

Drahos P., 2016. A Philosophy of Intellectual Property, Routledge, London.

Eisenberg R., Brinkley W.R., Comer W.T., Mazur B.J., Nelsen L.L., Rubin G.M., Winter S.G., 1996. Intellectual Property Rights and Research Tools in Molecular Biology Summary of a Workshop Held at the National Academy of Sciences, National Research Council, Washington.

Intellectual Property Rights and Research Tools in Molecular Biology. Summary of a Workshop Held at the National Academy of Sciences, February 15-16, 1996 National Research Council.

European Patent Office, 2019. Patent Index 2019 Statistics at a glance, epo.org/patentindex2019.

European Patent Office, 2018. a year of growth, https://www.epo.org/about-us/annualreports-statistics/annual-report/2018.html.

European Parliament, 2016. Directive (EU) 2016/943 of the European Parliament and of the Council of 8 June 2016 on the protection of undisclosed know-how and business information (trade secrets) against their unlawful acquisition, use and disclosure (Text with EEA relevance), http://data.europa.eu/eli/dir/2016/943/oj.

George A., 2017: Globalization and Intellectual Property, Routledge, London, DOI: 10.4324/9781315254111

Holger E. 2001. Patent applications and subsequent changes of performance: evidence from time-series cross-section analyses on the firm level, Research Policy, 30, 1, 143-157, DOI: 10.1016/S0048-7333(99)00098-0

Hong S., Counsellor, SMEs Division: 2003. The Magic of Patent Information, WIPO. Kasprzycki D., Matczewski A., Okoń-Horodyńska E., du Vall M., Wisła R., 2008. Zarządzanie własnością intelektualną w przedsiębiorstwie - regulaminy korzystania z wyników prac intelektualnych powstałych w przedsiębiorstwie, Uniwersytet Jagielloński, Kraków, 2-35. 
Kur A., Dreier T., Luginbuehl S., 2019. European Intellectual Property Law: Text, Cases and Materials, Second Edition, Edward Elgar Publishing.

McKeough J., 1996. Intellectual property and scientific research, Australian Journal of Physiotherapy, 42, 3, 235-242, DOI: 10.1016/S0004-9514(14)60390-1

Menell P.S., Lemley M.A., Merges R.P., 2019. Intellectual Property in the New Technological Age: 2019, Vol. II: Copyrights, Trademarks \& State IP Protections, Clause 8 Publishing, $2-38$.

Merges R.P., 1995. The economic impact of intellectual property rights: An overview and guide, Journal of Cultural Economics, 19, 103-117.

Ministerstwo Rozwoju Departament Strategii Rozwoju, 2017. Przedsiębiorczość w Polsce, Warszawa.

Pila J., Torremans P., 2019. European Intellectual Property Law, Oxford University Press.

Priebe M., 2019, Wycena Praw Własności Przemysłowej, https://www.chwp.pl/wycenapraw-wp/.

Rushing F.W., 2019. Intellectual Property Rights In Science, Technology, And Economic Performance: International Comparisons, Routledge.

Smyth S.J., McPhee-Knowles S., Baker A., Philips P.BW., 2013. Developing a patent landscape methodology, Queen Mary Journal of Intellectual Property, 3, 3, 251-266. 